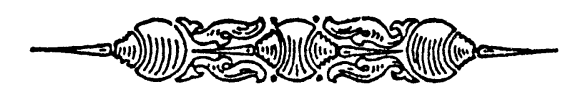

\title{
THE CHICKPEA, SUMMER CROPPING, AND A NEW MODEL FOR PULSE DOMESTICATION IN THE ANCIENT NEAR EAST
}

\author{
Shahal Авbo \\ The Hebrew University of Jerusalem \\ Rehovot 76100, Israel \\ E-MAIL:ABBO@AGRI.HUJI.AC.IL \\ Dan Shtienberg \\ Department of Plant Pathology, Agricultural Research Organization, The Volcani Center \\ Bet Dagan 50250, Israel \\ E-MAIL: DANISH@VOLCANI.AGRI.GOV.IL \\ JUdith LichtenzVEIG \\ The Hebrew University of Jerusalem \\ Rehovot 76100, Israel \\ Simcha LeV-Yadun \\ Department of Biology, Faculty of Science and Science Education, University of Haifa-Oranim \\ Tivon 36006, Israel \\ E-MAIL: LEVYADUN@RESEARCH.HAIFA.AC.IL

\section{Avi Gopher} \\ Sonia and Marco Nadler Institute of Archaeology, Tel-Aviv University \\ Tel-Aviv 69978, Israel \\ E-MAIL:AGOPHER@CCSG.TAU.AC.IL

\begin{abstract}
KEYWORDS
chickpea, crop evolution, legume domestication, Neolithic Revolution,
\end{abstract} \\ summer cropping
}

\section{ABSTRACT}

The widely accepted models describing the emergence of domesticated grain crops from their wild type ancestors are mostly based upon selection (conscious or unconscious) of major features related either to seed dispersal (nonbrittle ear, indehiscent pod) or free germination (nondormant seeds, soft seed coat). Based on the breeding systems (self-pollination) and dominance relations between the allelomorphs of seed dispersal mode and seed dormancy, it was postulated that establishment of the domesticated forms and replacement of the wild ancestral populations occurred in the Near East within a relatively short time. Chickpea (Cicer arietinum L.), however, appears as an exception among all other "founder

The Quarterly Review of Biology, December 2003, Vol. 78, No. 4

Copyright (C) 2003 by The University of Chicago. All rights reserved. 0033-5770/2003/7804-0003\$15.00 
crops" of Old World agriculture because of its ancient conversion into a summer crop. The chickpea is also exceptional because its major domestication trait appears to be vernalization insensitivity rather than pod indehiscence or free germination. Moreover, the genetic basis of vernalization response in wild chickpea (Cicer reticulatum Ladiz.) is polygenic, suggesting that a long domestication process was imperative due to the elusive phenotype of vernalization nonresponsiveness. There is also a gap in chickpea remains in the archaeological record between the Late Prepottery Neolithic and the Early Bronze Age. Contrary to the common view that Levantine summer cropping was introduced relatively late (Early Bronze Age), we argue for an earlier (Neolithic) Levantine origin of summer cropping because chickpea, when grown as a common winter crop, was vulnerable to the devastating pathogen Didymella rabiei, the causal agent of Ascochyta blight. The ancient (Neolithic) conversion of chickpea into a summer crop required seasonal differentiation of agronomic operation from the early phases of the Neolithic revolution. This topic is difficult to deal with, as direct data on seasonality in prehistoric Old World field crop husbandry are practically nonexistent. Consequently, this issue was hardly dealt with in the literature. Information on the seasonality of ancient (Neolithic, Chalcolithic, and Early Bronze Age, calibrated 11,500 to 4,500 years before present) Near Eastern agriculture may improve our understanding of the proficiency of early farmers. This in turn may provide a better insight into Neolithic agrotechniques and scheduling. It is difficult to fully understand chickpea domestication without a Neolithic seasonal differentiation of agronomic practice because the rapid establishment of the successful Near Eastern crop package which included wheats, barley, pea, lentil, vetches, and flax, would have preempted the later domestication of this rare wild legume.

$\mathbf{R}_{\text {ted }}$ ECONSTRUCTING SEASONALITY may be of importance in understanding organizational aspects of ancient economy, society, and settlement patterns. Identifying seasonal variation in agronomic operations may also provide better insight into crop evolution and the development of agrotechniques in antiquity. Direct evidence concerning seasonality in prehistoric field crop husbandry is practically nonexistent. The indirect method of ${ }^{13} \mathrm{C}$ discrimination, as evidence for the seasonal water status of plants, may serve to indicate the season of seed ripening (under known climatic rhythm) (Slafer et al. 1999). Even with very accurate ${ }^{13} \mathrm{C}$ data, however, it is not possible to differentiate between locally grown grains and traded seeds from other sites with different soil moisture availability.

In this review we discuss seasonality in prehistoric Near Eastern agriculture from a new perspective, based on the biology of the chickpea (Cicer arietinum L.) and its wild progenitor (C. reticulatum Ladiz.), the epidemiology of the two species, and their archaeobotanical remains in Near Eastern sites. We suggest a possible scenario for the emergence of the summer cropping practice in Near Eastern agriculture, thereby addressing some unanswered questions in Near Eastern crop evolution. This may shed new light on possible connections and directions of cultural exchange through agriculture.

\section{Agronomic Considerations}

The phenological rhythm of most annual Near East flora follows a pattern of germination in autumn, flowering in late winter/early spring, and maturation in early summer (Zohary 1966, 1972; Feinbrun-Dothan 1978, 1986). This cycle is also typical of all wild progenitors of the "founder crops" of Near Eastern agriculture. This crop package includes einkorn wheat (Triticum monococcum L.), emmer wheat (T. turgidum L.), barley (Hordeum vulgare L.), lentil (Lens culinaris Medic.), pea (Pisum sativum L.), chickpea, bitter vetch (Vicia ervilia (L.) Willd.), and flax (Linum usitatissimum L.) (Zohary and Hopf 2000). With respect to seasonality under domestication, all of the above cultivated forms have retained their autumnal germination/spring flowering/summer maturation cycle, with one exception-the chickpea. Across the Near East and the Mediterranean basin, the chickpea is a spring-sown crop, and a prominent element in traditional summer cropping (Elazari-Volcani 1930). The earliest recorded evidence for this practice is probably from Hellenistic and Roman times (Theophrastus 1916; Pliny 1938), describing chickpea sowing in March/April.

In the Near East, more than $80 \%$ of the precipitation occurs between December and February, and the long summer is hot and 
dry. Therefore, a dryland crop sown from late February onwards is dependent mainly on stored soil moisture, a fact that severely restricts its yield potential and stability. This is well illustrated by mean grain yields of Arab farmers in the village of Tel-A'ads (in the Jezreel Valley, Israel, south of Nazareth) between 1914 and 1923 (Elazari-Volcani 1930). Winter cereal yields ranged from 0.4 to 0.95 tons per hectare (mean $0.7 \mathrm{t} / \mathrm{ha}$, standard deviation $(\mathrm{SD})=0.17)$. Other crop yields were more variable. Grain legume yields (including winter horsebean, summer chickpea, and lentil) ranged from 0.24 to $1.3 \mathrm{t} /$ ha (mean 0.65 $\mathrm{t} / \mathrm{ha}, \mathrm{SD}=0.37)$. Yields of sorghum (Sorghum bicolor (L.) Moench, a summer crop) ranged from 0.06 to $0.85 \mathrm{t} /$ ha (mean 0.3 $\mathrm{t} / \mathrm{ha}, \mathrm{SD}=0.27)$, and yields of sesame (Sesamum indicum L., another summer crop) ranged from 0.1 to $1.0 \mathrm{t} / \mathrm{ha}$ (mean $0.3 \mathrm{t} / \mathrm{ha}$, $\mathrm{SD}=0.3)$ (Elazari-Volcani 1930). In presentday Israel and its neighboring countries, dryland chickpea planted in autumn may yield more than $3 \mathrm{t} / \mathrm{ha}$, compared with less than $0.7 \mathrm{t} / \mathrm{ha}$ of a spring-planted crop (Kostrinski 1974; Singh et al. 1997). Because yield stability is fundamental for any agricultural community, the inevitable conclusion is that winter cropping should be the practice of choice in the Near East.

Therefore, there must have been a very good agronomic/biological reason for sacrificing the high-yield potential of autumn sowing for the much lower (and unstable) yield of spring-sown chickpea, a change in practice that introduces the concept of seasonal differentiation in ancient agronomic practice.

\section{EPidemiological Considerations}

In the Near East, chickpea has been sown for millennia in the spring and grown as a summer crop. Why did ancient farmers dispense with autumn sowing despite all its benefits? The possibility of autumn sowing of chickpea was first tested by Israeli agronomists during 1950 to 1970 (Kostrinski 1974). From the very early seasons of autumn sowing, it became clear that the major limiting factor is Ascochyta blight, which has the potential to cause total yield loss (Kostrinski 1974). Later, a detailed comparison of winter and spring sowing of chickpea was conducted in the autumn of 1976 and in the spring of 1977 by ICARDA in Syria. In the autumnsown trial, all entries except one survived the winter. Then, with the onset of spring, Ascochyta blight appeared and subsequently destroyed almost all entries. However, one entry (NEC 2305) showed moderate resistance to the disease and produced a yield of over $3 \mathrm{t} / \mathrm{ha}$. Although the spring-sown trial escaped the disease, yields were substantially lower than the potential $3 \mathrm{t} / \mathrm{ha}$, with NEC 2305 yielding only $0.95 \mathrm{t} / \mathrm{ha}$ (Hawtin and Singh 1984). Over the next 10 years these results were confirmed in a follow-up study conducted in Syria and Lebanon. Wintersown chickpea cultivars resistant or partially resistant to Ascochyta produced 70\% more seed yield than the spring-sown crop, and yields were more stable than in the springsown crop (Singh et al. 1997). Susceptible cultivars sown in the winter did not yield at all. These studies clearly demonstrated that Ascochyta blight, rather than freezing temperatures or any other abiotic stress, is the reason that farmers in the Near East sow chickpeas in the spring.

Ascochyta blight is a fungal disease caused by Didymella rabiei (Kovachevski) von Arx [anamorph: Ascochyta rabiei (Passerini) Labrousse]. It is one of the most important diseases of chickpea worldwide (Nene 1982; Nene and Reddy 1987; Akem 1999), affecting all aerial parts of the plants. On leaflets, the fungal lesions are round or elongated, bearing irregularly depressed brown dots, and surrounded by brownish red margins. On the green pods, the lesions are usually circular with dark margins and have pycnidia arranged in concentric circles. Often, the infected seeds carry lesions. On stems and petioles, the lesions are brown and elongated (3 to $4 \mathrm{~cm}$ ), bearing black dots and often girdling the affected portion. When lesions girdle the stem, the portion above the point of attack rapidly dies. If the main stem is girdled at the collar region, the whole plant dies. As the disease spreads, patches of diseased plants become predominant and eventually affect the entire field (Nene 1984). Under environmental conditions that favor development of the pathogen, the disease is devastating. Crops are destroyed and yield losses 
reach $100 \%$ (Nene 1984; Akem 1999). Like many other pycnidial fungi, the pathogen spreads mainly by rainsplash of pycnidiospores (Nene 1984; Fitt et al. 1989). Although temperature and wind influence disease development and spread, rainfall is probably the critical factor in most Ascochyta epidemics and the disease develops whenever there are rains during the cropping season (Nene and Reddy 1987; Reddy et al. 1990; Diekmann 1992; Akem 1999).

Lentil and pea, the two other grain legume species among the Near Eastern founder crops, are also infected by Ascochyta blights. In lentil, the causal agent of Ascochyta blight is A. fabae Spegazzini f. sp. lentis (Gossen and Morrall 1983). In pea, the disease is incited by a complex of three pathogens: $A$. pisi Libert, which causes leaf and pod spots; $A$. pinodes Jones, the conidial state of Mycosphaerella pinodes (Berkeley \& Bloxam) Vestergren, which causes blight; and Phoma medicaginis var. pinodella (Jones) Boerema [synonym of Ascochyta pinodella Jones], which causes foot rot (Ali et al. 1994). Ascochyta blight did not preclude winter sowing of these two legumes, however. One possible explanation for this is the difference in the effect of the disease on the various crops. Whereas severe Ascochyta blight infection in chickpea is devastating, effects of the disease in lentil and pea are less conspicuous. Although substantial yield losses may occur in pea and lentil, complete destruction of the plants is uncommon even under severe epidemics (Gossen and Morrall 1983; Bayaa et al. 1992; Ali et al. 1994; Tivoli et al. 1996; Morrall 1997). Thus, lentil and pea could have been sown in the winter, survived Ascochyta blight epidemics, and produced at least some yield.

How may this be related to seasonal differentiation of agronomic operations? The common view is that incipient farmers were fully aware of the devastating effects of Ascochyta blight on chickpea. In the Near East, the climatic conditions that favor spread of the disease occur from early February until early April. Since an autumn-sown crop would be in fully closed canopy by this time, an Ascochyta epidemic is likely to destroy it. Because the disease is not a problem in spring-sown chickpea, this may be considered the prime reason for chickpea spring sowing today as well as in antiquity. Based on current knowledge, it is impossible to infer how ancient farmers changed the chickpea sowing season. Was it merely by chance, through having observed disease-free late-emerging types (perhaps with longer seed dormancy)? Or was it the result of deliberate experimentation with sowing dates? At any rate, we would argue that this shift of sowing time must have occurred fairly early after the initiation of chickpea farming.

\section{Archaeological Considerations}

Remains of the wild forms of the above mentioned package species/founder crops (cereals and legumes) were found in preNeolithic sites of the Upper/Middle Euphrates (Figure 1), such as Tell Abu Hureyra (13,000 to 11,500 calibrated ${ }^{14} \mathrm{C}$ years before present, or Cal BP), Mureybet I (ca. 12,500 Cal BP), and further east at Hallan Cemi Tepesi $(12,500$ to 11,500 Cal BP). Wild forms were also found in Neolithic layers at Jerf elAhmar (11,000 Cal BP), Mureybet III (11,500 to 10,700 Cal BP), Djade (10,700 Cal BP), Cayönü (ca. 10,500 Cal BP), Qermez Dere (ca. 11,500 Cal BP), and M'lefaat (ca. 11,500 to 10,500 Cal BP) (van Zeist and Bakker-Heeres 1985, 1986; Garrard 1999; Lev-Yadun et al. 2000; Zohary and Hopf 2000). Domesticated forms of cereals (einkorn, emmer wheat, and barley) appear in Neolithic layers as early as ca. 10,500 Cal BP at Tell Abu Hureyra 2A, Mureybet IV, Cafer Hüyük, Çayönü, and Nevali Cori. Domesticated pulses appear in the northern Levant and later in the southern Levant around 10,500 to 9,500 Cal BP (Garrard 1999; Zohary and Hopf 2000). Recent suggestions for a much earlier domestication of rye (Secale cereale L.) (ca. 13,000 Cal BP) at Tell Abu Hureyra shed new light on the history of cereal domestication in the Levant (Hillman et al. 2001). At the same site, largeseeded legumes (most probably in their wild form, but possibly cultivated) first appear in the archaeological record in strata dated to the 13th millennium Cal BP (Hillman 2000). In general, it seems that dates for domesticated crop forms (both cereals and legumes) are earlier in the northern Levant than in the southern Levant (Lev-Yadun et al. 2000), an 


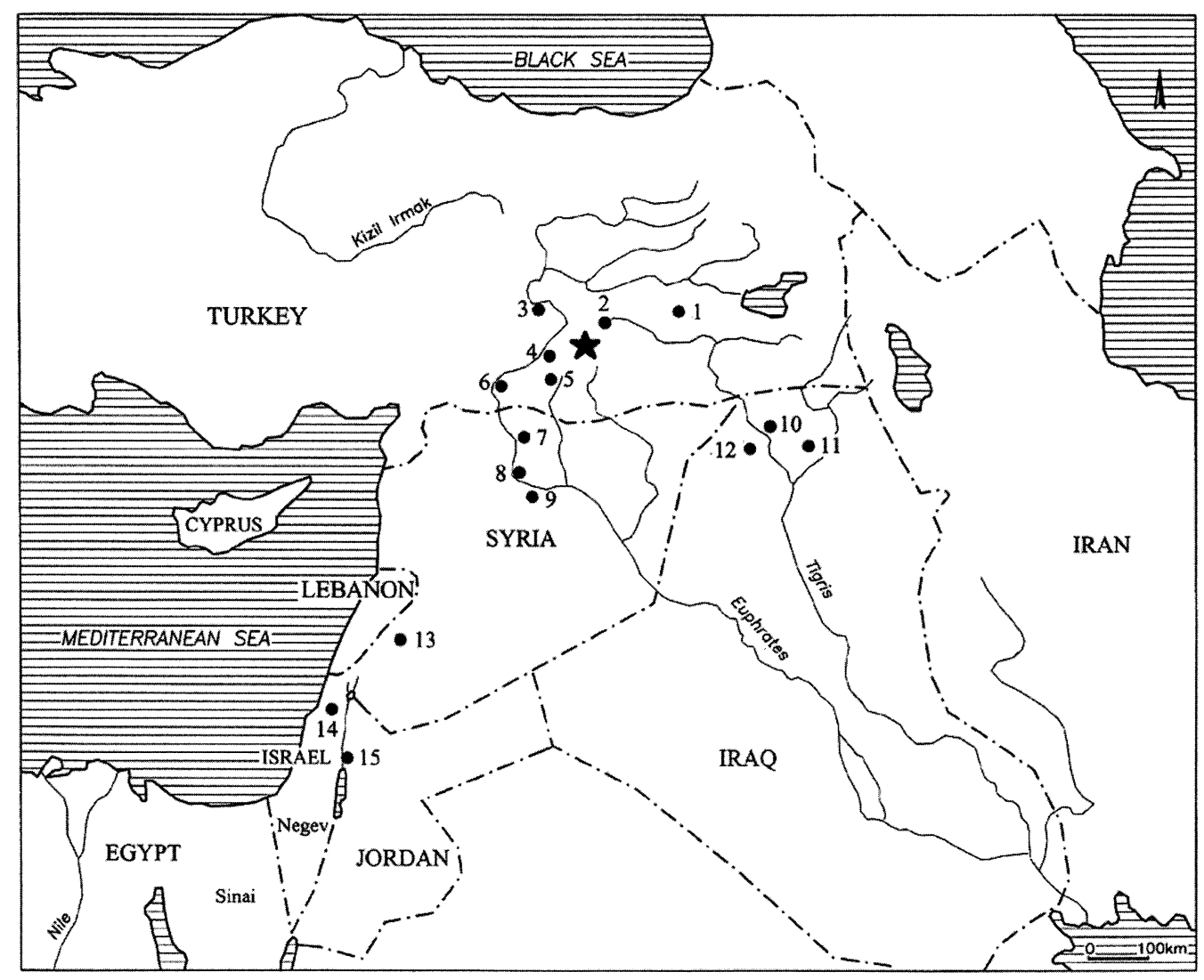

Figure 1. Map of the Near Eastern Archaeological Sites Mentioned in the Text

1. Hallan Çemi Tepesi; 2. Çayönü; 3. Cafer Höyük; 4. Nevalli Çori; 5. Göbekli Tepe; 6. Dja'de; 7. Jerf el Ahmar; 8. Mureybet; 9. Tell Abu Hureyra; 10. Nemrik; 11. M’lefaat; 12. Qermez Dere; 13. Tell Aswad; 14. Yiftahel; 15. Jericho, Netiv Hagdud, and Gilgal. Large asterisk for Karacadag, within the suggested core area for the origin of Near Eastern agriculture.

observation that accords with the new data from Tell Abu Hureyra (Hillman 2000; Hillman et al. 2001). All package/founder crop species appear in increasing quantities, establish themselves, and become part of the record despite preservation problems and limited archaeological recovery. However, chickpea shows a different temporal pattern in the archaeological record (Figure 2) compared to that of its companion grain legume species, pea and lentil: it appears, vanishes, and then reappears in the Early Bronze Age.

The history of chickpea appearance in the archaeological record may have started with the appearance of "large seeded legumes" of the 13th millennium Cal BP at Tell Abu Hureyra, which may have included chickpea
(Garrard 1999: Table 2; Hillman 2000). At a later stage (ca. 10,500 Cal BP), chickpea appears at Çayönü (van Zeist 1972). Both of these sites are very close to the natural distribution range of $C$. reticulatum, the immediate wild progenitor of domesticated chickpea. Later still, chickpea appears far away from its origin (an indication for domestication) in the Prepottery Neolithic (PPN) B at Jericho (mid-10th millennium Cal BP) (Garrard 1999) and at Ain Ghazal (10th millennium Cal BP; not clear which part of the middle PPNB) (Rollefson 1985) in the southern Levant, and in late PPNB at Tell Ramad in the Damascus basin (ca. 8,800 Cal BP) (van Zeist and Bakker-Heeres 1985; Garrard 1999: Tables 4,5 ). There appears to be a break in 


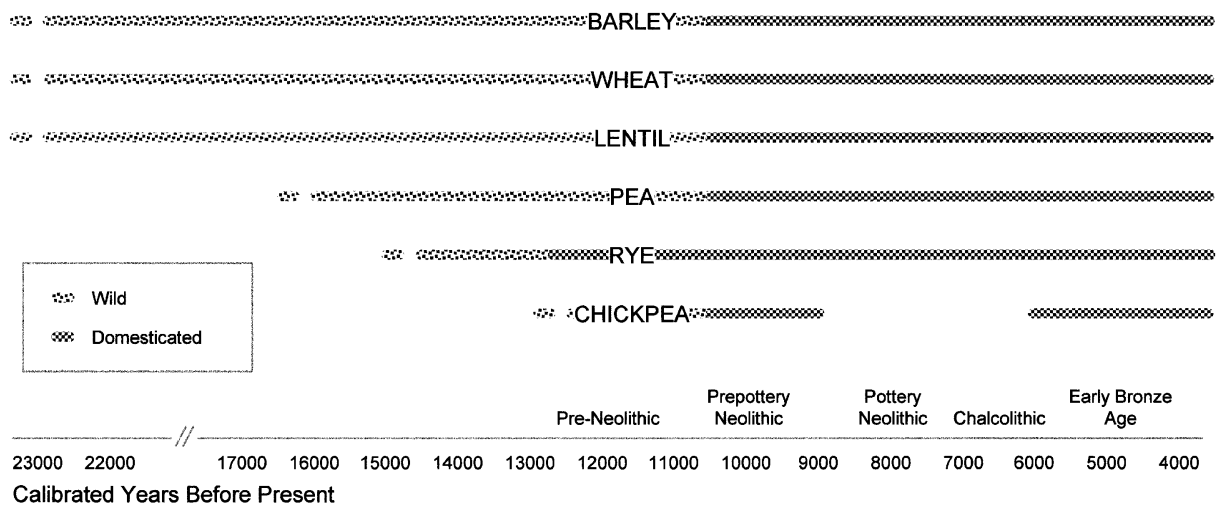

Figure 2. The Presence of Founder Crop Plants (and Rye) in the Archaeological Record of the LEVANT

All founder crop species appear in increasing quantities throughout the pre-Neolithic periods, and become part of the record despite the limited archaeological recovery. However, chickpea shows a different temporal pattern: it appears, vanishes, and then reappears in the Early Bronze Age away from its area of origin.

chickpea records from sites of the very end of the PPN (PPNC/final PPNB; 8,800 to 8,400 Cal BP), the Pottery Neolithic period $(8,400$ to $7,150 \mathrm{Cal} \mathrm{BP})$, the Chalcolithic period $(7,150$ to $6,100 \mathrm{Cal} \mathrm{BP})$, and the very beginning of the Early Bronze Age (6,100 to 5,750 Cal BP) in the Levant. Chickpea "reappears" later in the Early Bronze Age (post 5,750 Cal BP) sites, for example, at Arad and Jericho (Hopf 1978; Hopf 1983) and at Bab edhDhra' (McCreery 1979). Chickpea seeds are easily recognized by their typical beak from other Vicieae genera, so their absence from the record is therefore significant. Chickpea is mentioned in the Mediterranean basin in the mid-6th to mid-5th millennia Cal BP and in the Indian subcontinent at Harrapan settlements (at the very end of the 7th, 6th, and 5 th millennia Cal BP) (Zohary and Hopf 2000). Of interest is a single chickpea seed from the 9th millennium Cal BP site of Otzaki, Thessaly, Greece, and more finds of chickpea from the 7th millennium Cal BP site of Dimini, Greece (Zohary and Hopf 2000). Being far from the domestication "core area" (LevYadun et al. 2000; Gopher et al. 2001), these isolated finds seem to deviate from the pattern presented above if the latter is taken to represent part of the Levantine systemwhich we think is not the case. In summary, the chickpea is exceptional in its Near Eastern archaeological record because of its biphasic frequency distribution (Figure 2).

The difficulty of growing chickpea as a winter crop (see EPIDEMIOLOGICAL CONSIDERATIONS above) might explain the scarcity of chickpea seed in the record of Near Eastern Pottery Neolithic/Chalcolithic and the beginning of Early Bronze Age sites (ca. 8,800 to 5,750 Cal BP) compared with other grain species. The question then arises: could this scarcity be related to the different seasonal requirement for successful chickpea cropping, and if so, could it be used to formulate a model for the possible cultural source of seasonality in agronomic practice in the Near East?

\section{Discussion}

Two major difficulties attend this review. First, as already mentioned, there is no direct and unequivocal archaeological evidence for seasonality of agronomic practice in Neolithic times. Second, there is a considerable gap in knowledge of early Near Eastern agricultural traditions. This is because the earliest written 
records that describe summer cropping are the classical (Theophrastus 1916; Pliny 1938) and ancient Hebrew (Mishna) texts dating from ca. 2,300 BP to 1,700 BP. In earlier Hittite texts from the fourth millennium BP, in which Gú $\cdot$ Gal (identified as chickpea) is mentioned in ritual offerings, no details of farming practices are given (Hoffner 1974).

In recent Levantine traditional systems, the legume founder species are mainly winter crops. These include vetches (common and bitter), pea, and horsebean, although the latter species is usually not mentioned as one of the founder species, despite its long history in the Levant (Yiftahel; 9,800 Cal BP) (Kislev 1985). Lentil is sometimes sown in winter and in some instances in early spring, but usually considerably earlier in the season than chickpea. The only native Near Eastern springsown founder grain crop is chickpea (ElazariVolcani 1930).

Thousands of years after the initiation of farming in the Near East, and probably following contacts with other cultural centers in Asia and Africa, a number of crops with a "non-Mediterranean" life cycle were introduced into the Near East. Since these warmseason species do not suit the traditional autumn-sowing summer-maturation cycle typical of the Near Eastern founder grain crops (Elazari-Volcani 1930; Zohary and Hopf 2000), their cultivation required a different agrotechnique. Indeed, crops such as sorghum, broomcorn millet (Panicum miliaceum L.), foxtail millet (Setaria italica L.), rice (Oryza sativa L.), Old World cottons (Gossypium arboreum $\mathrm{L}$. and $G$. herbaceum $\mathrm{L}$.), and sesame are sown from March through May in the Near East, i.e., for summer cropping. The archaeological record for these warm-season species in the Near East is meager. There is no record of these species in reports of PPN, Pottery Neolithic or Chalcolithic periods (11,500 to 6,300 Cal BP) in the Levant. In the late stages of the Early Bronze Age (ca. 5,100 Cal BP), sorghum (mud brick imprints) was reported from Oman (Zohary and Hopf 2000) and appears also at Late Bronze Age sites (therein). Millets, rice, and sesame appear much later (Zohary and Hopf 2000).

Zohary and Hopf (1993) suggested that the tradition of summer cropping arrived in the
Near East with the import of the true warmseason crops like sorghum or sesame. They did not elaborate on that issue, but most probably based their argument on the life cycle of those summercrops, which differs from that of the majority of the native annual Near East flora. Accepting that suggestion, and considering the Near Eastern archaeological record, we have to conclude that the tradition of summer cropping started at least 6,000 to 5,000 years after the initiation of farming, i.e., in the Early Bronze Age.

Such relatively late development of summer cropping in the Near East may accord well with the discontinuity of chickpea presence in the archaeobotanical record (Figure 2). Once domesticated, chickpea was sown in autumn, and soon afterwards, when full-stand plots appeared, severe yield losses to Ascochyta blight probably occurred. As a result, chickpea may have been abandoned as a field crop and grown on a very limited scale as a garden crop, thus escaping the devastating effect of Ascochyta blight epidemics. According to this suggested reconstruction, chickpea remained in this state until the introduction of the true warm-season species from Africa/ Asia and the integration of summer-cropping practices into the Levantine systems. A "garden crop" phase of chickpea may well account for its later "reappearance." Support for such a status of chickpea in traditional Near Eastern agrosystems may be found in the relatively late report of Aaronsohn (1910), who mentioned a special chickpea land race, "They cultivated chick-peas in Tiberias, but only in kitchen gardens" (near the Sea of Galilee, Israel). Cultivation of chickpea as a garden crop (similar to garden pea) provides one possible explanation of the availablity of seed stocks for the Early Bronze Age "renaissance" of large-scale chickpea sowing, as suggested by the archaeological remains.

A possible alternative reconstruction is that summer cropping is a genuine Near Eastern development of older roots, predating the fairly late introduction of the African, Indian, and East Asian elements into the Near East. It is unclear whether the chickpea crop cycle in the initial stages of farming was similar to that in present-day Levantine traditional systems. However, the chickpea crop cycle 
described in the earliest written records (Theophrastus 1916; Pliny 1938) and in recent traditional systems is entirely different from that of its wild ancestor (Kumar and Abbo 2001). In its area of origin, wild chickpea (C. reticulatum) germinates after the autumn rains and develops vegetatively during the rainy winter. Flowering and reproduction occur in the late spring when mean temperatures are high and days are long. Interestingly, no resistance to Ascochyta blight was ever found in C. reticulatum (Singh and Reddy 1991; Singh 1997). However, the number of independent C. reticulatum accessions available for screening is rather limited so this latter point should be interpreted with caution.

It is assumed that the first cropping attempts were made with wild $C$. reticulatum types, so if the virulent pathogen was present in southeastern Turkey during the early days of farming, it was probably not long before full-canopy autumn-sown plots fell victim to the disease. A possible support for such a scenario is that Turkey is the center of distribution of a number of annual (including the immediate progenitor of the cultigen, C. reticulatum) and perennial Cicer species (van der Maesen 1972), several of which are indeed infected by $D$. rabiei when challenged under experimental conditions (Singh et al. 1998). However, in such a case it would be difficult to explain few millennia of autumn-sown chickpea production until 9,000 Cal BP, when the discontinuity of the archaeological record begins. An alternative explanation could be that the virulent pathogen was introduced into the region some 9,000 years ago, causing a dramatic decline in the archaeobotanic finds. The only record of D. rabiei, the Ascochyta blight pathogen from the wild, is from a perennial Cicer species in Bulgaria (Kaiser et al. 1998). Interestingly, according to the archaeological record, the farming culture that spread from its "core area" in southeastern Turkey reached the Balkans just before 8,000 Cal BP (Zohary and Hopf 2000). This could mark the approximate timing of the introduction of the virulent pathogen into the system, and the probable collapse of the chickpea autumn sowing practice.

The primary and secondary centers of origin of cultivated plant species are often also the places of origin of their pathogens (Leppik 1970). How did the virulent pathogen spread from the Balkans (its hereby assumed place of origin) to other cultivated areas? $D$. rabiei is an important seed-borne pathogen. In modern agriculture, infected seed is an important agent in the long-distance spread and survival of these pathogens. Seed transmission has been responsible for the introduction and dissemination of the Ascochyta blight pathogen in many countries worldwide (Kaiser 1997). Thus, it is likely that the disease spread via traded seed stocks.

The above lends support for the argument that spring sowing must have been the only possible way to secure a reliable chickpea yield in ancient times. Several assumptions underlie this argument. First, chickpea must have been sown in full stands rather than as a scattered garden plant. Second, during the initial cultivation attempts chickpea must have been a winter crop. Third, early chickpea cultivation must have taken place in regions with rainy winters, such as those of the Mediterranean climate. Accepting the above assumptions suggests a scenario in which incipient farmers had no choice but to postpone chickpea sowing until late in the season in order to escape Ascochyta blight, i.e., to practice summer cropping. In this context it is worth considering the following statement by Pliny (1938): "Rain is beneficial to crops while in the stalk from the time of germination, but it damages wheat and barley when in blossom; although it does no harm to leguminous plants, excepting chick-pea" (18.44.152). Although Pliny's compendium was written ca. eight millennia after the Neolithic revolution, the above citation reflects prevailing traditions from earlier periods. This suggests that even at times when spring sowing of chickpea was already an established practice, farmers (and scholars alike) were fully aware of the risk of growing chickpea during the rainy season.

No archaeological evidence for the presence of the pathogen in ancient times was ever presented, maybe because no one bothered to look for the fungus remains. Contrary to our arguments, this may suggest that the disease was not prevalent in antiquity and therefore did not limit chickpea winter crop- 
ping. Alternatively, and in line with our hypothesis, the absence of pathogen remains from excavated chickpea seeds could easily serve to indicate summer cropping of chickpea. This is because, following spring sowing, the disease would very rarely occur and will never take the form of an epidemic, contrary to the prevalence of Ascochyta epidemics in autumn-sown chickpea (Nene 1982; Hawtin and Singh 1984; Nene and Reddy 1987; Reddy et al. 1990; Diekmann 1992; Akem 1999). Accordingly, a disease free (springsown) crop is very unlikely to leave traces in the form of infected seeds remains.

As further support for the origin of spring sowing of chickpea in the ancient Near East, we should emphasize that it is difficult to explain millennia of repeated autumn sowing while facing repeated Ascochyta epidemics. Farmers are unlikely to cache seeds for more than one sowing season, let alone for a number of successive years. Moreover, there is no incentive for repeated sowing of an illadapted crop. Also, if autumn-sown chickpea fields were left unharmed by Ascochyta epidemics until the 6th millennium Cal BP (the suggested timing for the introduction of the African species to the Levant), why was it necessary to resort to summer cropping? One could argue that due to the effect of repeated Ascochyta epidemics, chickpea might have been neglected altogether as a crop plant for a long period, hence the discontinuity in occurrence of archaeological finds. Its reappearance in the record during the Early Bronze Age could therefore be seen as a "repeated domestication" after integration of the summer-cropping concept into Near Eastern agrotechniques. Based on the very restricted distribution of the wild progenitor of chickpea (Ladizinsky 1995), we tend to reject the "repeated domestication" hypothesis. While it is possible that current distribution of $C$. reticulatum is a relic of wider distribution in earlier periods, the current wider distribution of wild peas and lentils, which inhabit similar ecological niches, might suggest that this is not the case.

Because of the large, dense stands of wild wheat and barley (ca. $80 \%$ carbohydrate grain content), collection (from the wild) during the ripening season could provide a major part of the diet (Harlan 1967; Ladizinsky 1975). In contrast, collection from the small, scattered populations of wild lentils can provide only a negligible part of the diet (Ladizinsky 1987, 1993). Collection exercises of wild C. reticulatum were never reported, but the rarity of the species might suggest a similar conclusion regarding the potential contribution of foraged wild chickpea seeds to the diet. Therefore, in order to make pulse grains a major protein source (average content 25\% protein), domestication and/or cultivation of the species was imperative (Ladizinsky 1987), and great efforts were made to keep those species under cultivation. The intimate ancient association of humans with legume species (Kislev and Bar-Yosef 1988) might suggest that the incipient farmers were fully aware of the nutritional value of pulse grains. In all known centers of ancient plant domestication, both cereal (or carbohydrates rich tubers) and legume crops were indeed domesticated side by side. These include rice and soybean in Asia, corn and common beans in Central America, and sorghum and cowpea in Africa (Harlan 1992). We therefore believe that chickpea seed stocks were maintained by Near Eastern farmers throughout the period for which no archaeological record is currently available. This must have required a well-established agrotechnique, based on spring sowing/summer cropping, that was perpetuated from generation to generation. In our view, these considerations suggest an early native origin of the spring-sowing practice in the Near East.

Recent reports of safflower (Carthamus sp.) seeds from the 6th millennium Cal BP sites of northern Syria may provide additional circumstantial evidence for the Levantine origin of summer cropping (McCorriston 1998). These seeds could not have been definitely identified as belonging to either wild or domesticated forms. Cultivated safflower is a spring-sown crop, whereas wild safflower is a summer weed throughout the Near East. Unaware of any Bronze Age summer crops with which weedy safflower could have been associated, McCoriston suggests that those remains could indicate the start of safflower cultivation and probably mark the start of summer cropping in the Near East (Mc- 
Corriston 1998). Based on our considerations (above), and on chickpea remains from north Syrian sites of the 6th millennium Cal BP (McCorriston 1998) (and in the southern Levant-see above), we suggest that those Carthamus remains probably indicate an existing practice of (chickpea) summer cropping.

If summer cropping was introduced as early as the PPN it might have affected Neolithic land-use patterns and social organization in different ways (e.g., farmers' scheduling). Because winter and summer crops are parts of an integral system, this would mean a longer farming season: September to May/ June for winter crops, and March to August for summer crops. This sequence requires nearly year-round care. On the other hand, relying solely on summer cropping requires a relatively short period (4 months). Other implications may arise because winter and summer cropping partly overlap. This means that separate fields must be allotted for each type of crop each year, and a larger acreage must therefore be managed simultaneously. Animal husbandry, when introduced, may also have been affected because farming of both winter and summer crops means that the nutritious chickpea straw would be available from August onwards after the stubble of the cereals is grazed in early June. Early emergence of the summer-cropping practice may also be related to minimizing risks and improving the stability of the cropping system as a whole. As an example, a late start of the rainy season, followed by a mild spring, may enhance (spring-sown) chickpea yield, while reducing the yield of (autumn-sown) cereals (Elazari-Volcani 1930). There must have been an incentive for year-to-year yield stability from the very early days of the Neolithic revolution. Moreover, the fewer the cultivated species, the more critical the impact of any crop failure is likely to be for the farming community.

\section{Implications for NeAr EAst Crop EVOLUTION}

To date, only meager information is available on the genetics of the domestication traits of chickpea. It appears, however, that in this respect as well, chickpea is an exception among its companion Near Eastern grain legumes. Pod dehiscence and hard seed coatmediated dormancy are typical features of wild Pisum elatius/humile and Lens orientalis, the wild progenitors of pea and lentil, respectively (Werker et al. 1979; Ladizinsky 1985, 1987). In wild C. reticulatum, however, pod dehiscence is not a problem as most pods are retained intact at full maturity (Ladizinsky 1979). This led Ladizinsky to suggest that this trait must have attracted the attention of ancient food gatherers and probably made chickpea the most suitable and natural candidate of all Near Eastern grain legumes for domestication (Ladizinsky 1979). This accords well with the putative central role of chickpea in the site of origin of Near East farming (Lev-Yadun et al. 2000; Gopher et al. 2001). One might even wonder whether chickpea was the very first plant to be domesticated in the Near East. Interestingly, this is in line with earlier hypotheses concerning pulses as the earliest domesticants in the Near East (Kislev and Bar-Yosef 1988).

Hard seededness-mediated dormancy is atypical of wild C. reticulatum seeds. We have been testing a number of $C$. reticulatum accessions (Cr205, Cr231, Cr778, Cr86-09-01, CrSP-1) for this trait over a number of years and have frequently observed germination rates of $35 \%$ to $95 \%$ (S Abbo, S Lev-Yadun, L A Morrison, unpublished). Only one accession (Cr231) has consistently shown a relatively low rate of germination from year to year (ca. 25\%). This suggests that with respect to the "classical" domestication traits, namely seed dispersal mode and hard seededness, no dramatic genetic changes were required at the earliest stages of bringing chickpea under cultivation. This contrasts with pea, lentil, and the vetches, in which both soft-seeded mutants and indehiscent pod types were required to ensure successful cropping (Ladizinsky 1985, 1987, 1989, 1993; Zohary 1996).

Recent studies of the genetic basis of lowtemperature response of wild chickpea at the seedling stage (Abbo et al. 2002) have demonstrated clear phenological and morphological differences between wild and cultivated chickpea stocks following vernalization treatment. Wild C. reticulatum was highly respon- 
sive to the low-temperature treatment, whereas the cultivated stock did not respond. This putative vernalization response of wild chickpea is a major adaptive trait in its native growing area in eastern Turkey. However, any vernalization requirement may cause a severe yield penalty in a spring-sown species (Putnam et al. 1993; Abbo et al. 2002). Based on the genetic evidence and the seasonal climatic pattern in eastern Turkey, it was suggested that reducing the low-temperature requirement of wild chickpea (through selection of mutants that were not responsive to vernalization) was imperative to ensure successful summer cropping of chickpea (Abbo et al. 2002).

Based on the seed dispersal mode, germination rates, and vernalization requirements of wild chickpea ( $C$. reticulatum), we suggest a new model for chickpea domestication. In our view, the major genetic change underlying chickpea domestication was the shift to nonresponsiveness of the seedlings to low temperature (vernalization insensitivity). This is because reliable and relatively stable production of chickpea by means of summer cropping becomes feasible only after such a change. To the best of our knowledge, this is a new model for crop domestication. Thus far, seed dispersal mode and seed dormancy have been considered the fundamental traits in which major changes are required for successful farming (Harlan 1992; Ladizinsky 1998; Zohary and Hopf 2000). We are unaware of earlier studies suggesting vernalization insensitivity as the initial and major change underlying domestication of any one crop.

This model may provide an additional explanation for the gap in the occurrence of archaeological chickpea remains. The first phase probably corresponds to foraged seeds of wild forms or winter-planted wild forms. Obviously, initial attempts at spring sowing were done with vernalization-sensitive wild types. As mentioned above, this practice results in a severely curtailed yield, hence the decline in the archaeological finds. Only once vernalization-insensitive types had emerged and adaptation to spring sowing (hence yield) was improved could the fre- quency of the finds increase (Figure 2, late phase).

A vernalization-insensitive mutation is less conspicuous than the nonbrittle spike or indehiscent pod phenotypes. This is partly because wild $C$. reticulatum does not have an obligatory vernalization requirement (Abbo et al. 2002). Furthermore, current data on the genetic basis of the chickpea vernalization requirement point to a polygenic system (Abbo et al. 2002), although the participation of a major gene in such a system cannot be ruled out. Polygenic control might have necessitated a long selection process and a gradual change towards vernalization insensitivity. This slow domestication model is in sharp contrast with the rapid scenaria assumed for the classical domestication traits (e.g., nonbrittle spikes, soft seededness) of Near Eastern grain crops (Ladizinsky 1987; Zohary 1996). This may explain the relatively long gap between the two phases of the chickpea frequency distribution in the archaeological record (Figure 2).

A seemingly simpler explanation for the absence of chickpea seeds from Pottery Neolithic and Chalcolithic strata may be a change in the subsistence economy-from collecting a variety of wild legumes (Cicer included) to farming based on domesticated pulses (excluding chickpea). So, contrary to the common view of the founder crops package (Zohary and Hopf 2000), such a scenario would suggest that chickpea was actually domesticated only around about 5,700 BP. It is important to note that, based on current archaeological records, chickpea "reappears" far away (Arad, Jericho, Bab edh-Dhra') from its native region in southeast Turkey, which is a clear indication of cultivation. In our view it is highly unlikely that with the advent of a local and successful agricultural package (that includes the pulses lentil, pea, and horsebean, alongside cereals and farm animals) the Early Bronze Age people of the southern Levant would wander to the upper reaches of the Tigris and the Euphrates to search for a rare wild legume and take the trouble to domesticate such an agronomically problematic species. Moreover, if indeed chickpea was not maintained as a domesticated crop since the initiation of Neolithic farming, it is much 
easier to assume that the successful early domestication of lentil, pea, horsebean, and the vetches would have preempted the later domestication of this rare species, perhaps to this very day, as discussed elegantly by Diamond (1997).

Successful introduction of a new crop species (for example, from Africa or India) into a new growing area (Near East/Levant) depends on agrotechniques that allow successful vegetative development and timely reproduction out of its natural geographic range (Ladizinsky 1998). In the absence of an established (local or imported) agrotech- nique, the newly introduced species may be abandoned after very few cropping attempts. This may suggest that the prevailing habit of spring sowing of chickpea might have facilitated the introduction of the true warmseason species, like sesame or sorghum, into Near Eastern agrosystems.

\section{ACKNOWLEDGMENTS}

Shahal Abbo acknowledges grant support from the United States-Israel Binational Agricultural Research and Development Fund (grant number US-3034-98R) and the Chief Scientist's Fund of the Israeli Ministry of Agriculture.

\section{REFERENCES}

Aaronsohn A. 1910. Agricultural and Botanical Explorations in Palestine. Bulletin Number 180. Washington (DC): Government Printing Office.

Abbo S, Lev-Yadun S, Galwey N. 2002. Vernalization response of wild chickpea. New Phytologist 154:695701.

Akem C. 1999. Ascochyta blight of chickpea: present status and future priorities. International Journal of Pest Managemant 45:131-137.

Ali S M, Sharma B, Ambrose M J. 1994. Current status and future strategy in breeding pea to improve resistance to biotic and abiotic stresses. Euphytica 73:115-126.

Bayaa B, Erskine W, Hamdi A. 1992. Response of wild lentil to Ascochyta fabae f.sp. lentis from Syria. Genetic Resources and Crop Evolution 41:61-65.

Diamond J M. 1997. Guns, Germs, and Steel: The Fates of Human Societies. New York: W.W. Norton.

Diekmann M. 1992. Use of climatic parameters to predict the global distribution of Ascochyta blight on chickpea. Plant Disease 76:409-412.

Elazari-Volcani I. 1930. The Fellah's Farm. Bulletin Number 10. Tel Aviv (Israel): Jewish Agency for Palestine.

Feinbrun-Dothan N. 1978. Flora Palaestina. Volume 3. Jerusalem (Israel): Israel Academy of Sciences and Humanities.

Feinbrun-Dothan N. 1986. Flora Palaestina. Volume 4. Jerusalem (Israel): Israel Academy of Sciences and Humanities.

Fitt B D L, McCartney H A, Walklate P J. 1989. The role of rain in dispersal of pathogen inoculum. Annual Review of Phytopathology 27:241-270.

Garrard A. 1999. Charting the emergence of cereal and pulse domestication in southwest Asia. Environmental Archaeology 4:67-86.

Gopher A, Abbo S, Lev-Yadun S. 2001. The "when", the "where" and the "why" of the Neolithic revo- lution in the Levant. Documenta Praehistorica XXVIII:49-62.

Gossen B D, Morrall R A A. 1983. Effect of ascochyta blight on seed yield and quality of lentils. Canadian Journal Plant Pathology 5:168-173.

Harlan J R. 1967. Wild wheat harvest in Turkey. Archaeology 20:197-201.

Harlan J R. 1992. Crops and Man. Second Edition. Madison (WI): American Society of Agronomy/ Crop Science Society of America.

Hawtin G C, Singh K B. 1984. Prospects and potential of winter sowing of chickpeas in the Mediterranean region. Pages 7-16 in Ascochyta Blight and Winter Sowing of Chickpeas, Edited by M C Saxena and K B Singh. The Hague: Martinus Nijhoff/Dr W. Junk Publishers.

Hillman G C. 2000. The plant food economy of Abu Hureira 1 and 2. Pages 327-398 in Village on the Euphrates: From Foraging to Farming at Abu Hureya, edited by A M T Moore, G C Hillman, and A J Legge. Oxford: Oxford University Press.

Hillman G, Hedges R, Moore A, Colledge S, Pettitt P. 2001. New evidence of Lateglacial cereal cultivation at Abu Hureyra on the Euphrates. Holocene 11:383-393.

Hoffner H A. 1974. Alimenta Hethaeorum: Food Production in Hittite Asia Minor. New Haven (CT): American Oriental Society.

Hopf M. 1978. Plant remains strata V-I. Pages 64-82 in Early Arad I: The Chalcolithic Settlement and the Early Bronze Age City, edited by R Amiran et al. Jerusalem (Israel): Israel Exploration Society.

Hopf M. 1983. Jericho plant remains. Pages 576-621 in Excavations at Jericho, Volume 5, edited by $\mathrm{K} \mathrm{M}$ Kenyon. London: British School of Archaeology in Jerusalem.

Kaiser W J. 1997. Inter- and intranational spread of ascochyta pathogens of chickpea, faba bean, and 
lentil. Canadian Journal of Plant Pathology 19:215224.

Kaiser W J, Hannan R M, Meuhlbauer F J. 1998. First report of Ascochyta blight of Cicer montbretii, a wild perrenial chickpea in Bulgaria. Plant Disease 82:830.

Kislev M E. 1985. Early Neolithic horsebean from Yiftah'el Israel. Science 228:319-320.

Kislev M E, Bar-Yosef O. 1988. The legumes: the earliest domesticated plants in the Near East? Current Anthropology 29:175-179.

Kostrinski J. 1974. Problems in Chickpea Cultivation and Grain Crop Rotation in Israel. Special Report Number 34 (Hebrew, English summary). Bet Dagan (Israel): Agricultural Research Organization, Volcani Center.

Kumar J, Abbo S. 2001. Genetics of flowering time in chickpea and its bearing on productivity in semiarid environments. Advances in Agronomy 72:107138.

Ladizinsky G. 1975. Collection of wild cereals in the upper Jordan Valley. Economic Botany 29:264-267.

Ladizinsky G. 1979. Seed dispersal in relation to the domestication of Middle East legumes. Economic Botany 33:284-289.

Ladizinsky G. 1985. The genetics of hard seed coat in the genus Lens. Euphytica 34:539-543.

Ladizinsky G. 1987. Pulse domestication before cultivation. Economic Botany 41:60-65.

Ladizinsky G. 1989. Pulse domestication: facts and fiction. Economic Botany 43:131-132.

Ladizinsky G. 1993. Lentil domestication: on the quality of evidence and arguments. Economic Botany 47:60-64.

Ladizinsky G. 1995. Chickpea. Pages 258-261 in Evolution of Crop Plants, Second Edition, edited by J Smartt and N W Simmonds. Harlow (UK): Longman Scientific \& Technical.

Ladizinsky G. 1998. Plant Evolution under Domestication. Dordrecht (The Netherlands): Kluwer Academic Publishers.

Leppik E E. 1970. Gene centers of plants as sources of disease resistence. Annual Review of Phytopathology 8:323-344.

Lev-Yadun S, Gopher A, Abbo S. 2000. The cradle of agriculture. Science 288:1602-1603.

McCorriston J. 1998. Syrian origins of sufflower production: new discoveries in the agrarian prehistory of the Habur basin. Pages 39-48 in The Origins of Agriculture and Crop Domestication of Crop Plants in the Near East, edited by A B Damania, J Valkoun, G Willcox, and C O Qualset. Aleppo (Syrai): ICARDA.

McCreery D. 1979. Floatation of the Bab edh-Dhra and Numeila plant remains. Annals of the American School of Orient Research 46:165-169.

Morrall R A A. 1997. Evolution of lentil diseases over
25 years in western Canada. Canadian Journal of Plant Pathology 19:197-207.

Nene Y L. 1982. A review of Ascochyta blight of chickpea. Tropical Pest Management 28:61-70.

Nene Y L. 1984. A review of Ascochyta blight of chickpea (Cicer arientum L.). Pages 17-33 in Ascochyta Blight and Winter Sowing of Chickpeas, edited by M C Saxena and K B Singh. The Hague: Martinus Nijhoff/Dr W. Junk Publishers.

Nene Y L, Reddy M V. 1987. Chickpea diseases and their control. Pages 233-270 in The Chickpea, edited by M C Saxena and K B Singh. Oxon (UK): CAB International.

Pliny, the Elder. 1938. Natural History, Loeb Classic Library, translated by H Rackham. [1971 reprint.] Cambridge (MA): Harvard University Press.

Putnam D H, Simmons S R, Hardman L L. 1993. Vernalization and seeding date effects on yield and yield components of white lupin. Crop Science 33:1076-1083.

Reddy M V, Nene Y L, Singh G, Bashir M. 1990. Strategies for management of foliar diseases of chickpea. Pages 117-127 in Chickpea in the Winter, edited by $\mathrm{H} A$ van Rheenen and M C Saxena. Patancheru (India): ICRISAT.

Rollefson G O. 1985. The 1983 season at the Early Neolithic site of Ain Ghazal. National Geographic Research 1:44-62.

Singh K B. 1997. Chickpea (Cicer arietinum L.). Field Crops Research 53:161-170.

Singh K B, Malhotra R S, Saxena M C, Bejiga G. 1997. Superiority of winter sowing over traditional spring sowing of chickpea in the mediterranean region. Agronomy Journal 89:112-118.

Singh K B, Ocampo B, Robertson L D. 1998. Diversity for abiotic and biotic stress resistance in the wild annual Cicer species. Genetic Resources and Crop Evolution 45:9-17.

Singh K B, Reddy M V. 1991. Advances in disease-resistance breeding in chickpea. Advances in Agronomy 45:191-222.

Slafer G A, Ramagosa I, Araus J L. 1999. Durum wheat and barley yields in antiquity estimated from ${ }^{13} \mathrm{C}$ discrimination of archaeological grains: a case study from the western Mediterranean basin. Australian Journal of Plant Physiology 26:345 - 352.

Theophrastus. 1916. Enquiry into Plants and Minor Works on Odours and Weather Signs, Loeb Classic Library, translated by A F Hort. [1968 reprint.] Cambridge (MA): Harvard University Press.

Tivoli B, Béasse C, Lemarchand E, Masson E. 1996. Effect of ascochyta blight (Mycosphaerella pinodes) on yield components of single pea (Pisum sativum) plants under field conditions. Annals of Applied Biology 129:207-216.

van der Maesen L J G. 1972. Cicer L., A Monograph of the Genus, with Special Reference to the Chickpea (Cicer 
arietinum L.), its Ecology and Cultivation. Wageningen (The Netherlands): H. Veenman \& Zonen.

van Zeist W. 1972. Paleobotanical results in the 1970 season at Cayönü Turkey. Helinium 12:3-19.

van Zeist W, Bakker-Heeres J A H. 1985. Archaeological studies in the Levant. 1. Neolithic sites in the Damascus basin: Aswad, Ghoraifé, Ramad. Palaeohistoria 24:165-256.

van Zeist W, Bakker-Heeres J A H. 1986. Archaeological studies in the Levant. 3. Late paleolithic Mureybet. Palaeohistoria 26:171-199.

Werker E, Marbach I, Mayer A M. 1979. Relation between the anatomy of the testa, water permeability and the presence of phenolics in the genus Pisum. Annals of Botany 43:765-771.

Zohary D. 1996. The mode of domestication of the founder crops of the Southwest Asian agriculture.
Pages 142-158 in The Origins and Spread of Agriculture and Pastoralism in Eurasia, edited by D R Harris. London: UCL Press.

Zohary D, Hopf M. 1993. Domestication of Plants in the Old World: The Origin and Spread of Culitvated Plants in West Africa, Europe, and the Nile Valley. Second Editon. Oxford: Clarendon Press.

Zohary D, Hopf M. 2000. Domestication of Plants in the Old World: The Origin and Spread of Culitvated Plants in West Africa, Europe, and the Nile Valley. Third Edition. Oxford: Clarendon Press.

Zohary M. 1966. Flora Palaestina. Volume 1. Jerusalem (Israel): Israel Academy of Sciences and Humanities.

Zohary M. 1972. Flora Palaestina. Volume 2. Jerusalem (Israel): Israel Academy of Sciences and Humanities. 


\section{THE QUARTERLY REVIEW OF BIOLOGY \\ Page Charge and Offprint Order Form}

This form must be returned with your manuscript and a corrected set of proofs within 48 hours of receipt. Authors are entitled to 10 complimentary copies of the journal issue or a year's subscription (or renewal) free of charge; however, we cannot send them until we have received this form. Please see the reverse of this form for a list of offprint prices.

\section{PAGE CHARGES}

Authors who attribute support to funding agencies will be expected to meet charges of $\$ 40$ per journal page for each of the first 20 journal pages, and $\$ 80$ for each journal page in excess of 20 . Authors not supported by funding agencies and authors of invited articles are eligible for 20 free journal pages (approximately 50 double-spaced typewritten manuscript pages or their equivalent in bibliographic or illustrative matter). When such articles are longer than 20 journal pages, authors will be charged $\$ 80$ for each page above the allotment of 20 free journal pages. These charges will be used for direct support of the issue in which the article appears.

\section{Author(s)}

Article title:

Page length of article:

In order to determine the length of your article, please count the number of paged galleys. The cost of author alterations is chargeable to the author and will be invoiced after the article is published, along with the cost of offprints and page charges.

\section{OFFPRINTS}

\begin{tabular}{|l|l|}
\hline $\begin{array}{l}\text { Check } \\
\text { Quantity* }\end{array}$ & Check only one: \\
\hline ( ) offprints without covers & ( ) 10 free copies of the journal issue \\
\hline ( ) offprints with covers & \multicolumn{1}{c|}{ OR } \\
\hline ( ) I do not want offprints & ( ) free year's subscription or renewal \\
\hline
\end{tabular}

*Order offprints in multiples of $\mathbf{5 0}$

SHIP TO:

BILL TO (for page charges and offprints):

\begin{tabular}{|l|l|}
\hline & \\
\hline & \\
\hline & \\
\hline & \\
\hline
\end{tabular}

PURCHASE ORDER NUMBER: FOLLOW

（ ) ATTACHED （）WILL

Signature:

Daytime telephone number:

FAX: 


\section{OFFPRINT PRICES}

ARTICLE LENGTH IN PAGES

\begin{tabular}{|l|l|l|l|l|l|l|l|l|l|l|l|r|}
\hline Copies & $\mathbf{4}$ & $\mathbf{6}$ & $\mathbf{8}$ & $\mathbf{1 0}$ & $\mathbf{1 2}$ & $\mathbf{1 4}$ & $\mathbf{1 6}$ & $\mathbf{1 8}$ & $\mathbf{2 0}$ & $\mathbf{2 2}$ & $\mathbf{2 4}$ & Covers \\
\hline 50 & $\$ 24$ & 31 & 44 & 54 & 61 & 74 & 84 & 94 & 104 & 114 & 125 & $\$ 70$ \\
\hline 100 & $\$ 30$ & 42 & 54 & 67 & 80 & 92 & 105 & 117 & 130 & 142 & 155 & $\$ 85$ \\
\hline 150 & $\$ 35$ & 50 & 65 & 80 & 95 & 110 & 125 & 140 & 155 & 170 & 181 & $\$ 100$ \\
\hline 200 & $\$ 40$ & 58 & 75 & 93 & 110 & 128 & 146 & 163 & 181 & 198 & 216 & $\$ 115$ \\
\hline $\begin{array}{l}\text { each } \\
\text { add'1 } 50\end{array}$ & 6 & 8 & 11 & 13 & 16 & 19 & 21 & 24 & 26 & 29 & 32 & $\$ 15$ \\
\hline
\end{tabular}

Offprint prices are in dollar amounts.

The cost for covers (one color, half-title) is in addition to the cost of offprints.

For longer articles, combine rates; e.g., 30 pages $=24+6$

\section{SHIPPING}

Offprints are shipped within 21 days of the printing of the issue. The above prices include postage for domestic orders. CANADIAN ORDERS: For each 50 copies, add \$3.50 to the total. OTHER FOREIGN ORDERS: For each 50 copies, add $\$ 5.50$ to the total.

\section{LATE ORDERS}

The prices listed above apply only to orders placed by authors before publication of the journal issue. After the journal is published, estimates for reprints in multiples of 100 may be obtained from Journals Production, The University of Chicago Press, 1427 E. 60 ${ }^{\text {th }}$ Street, Chicago, IL 60637, Attention: Reprints Desk.

\section{INSTITUTIONAL ORDERS}

Please list VENDOR as: The Quarterly Review of Biology, The University of Chicago Press, 11030 South Langley Avenue, Chicago, IL 60628. If a purchase order is sent separately from this order form, it must be received before the publication of the journal issue and must be marked "Confirming." All purchase orders must include journal name, issue date, author's name, and the number of offprints and covers desired. Institutional orders without a purchase order will not be processed.

\section{CREDIT CARD ORDERS}

Payment for page charges and offprints can be made with Mastercard or Visa. Please complete all information requested below and include your signature and the expiration date of your card.

Cardholder name as it appears on card:

Card number:

Expiration date:

Signature:

Your Mastercard or Visa account will be charged after shipment of your offprints. 